\title{
Needs Analysis of English for Specific Purposes on Islamic Boarding School Students
}

\begin{abstract}
Helmi Abdul Latif
Master Program in Linguistics, Diponegoro University, Indonesia

Correspondence: Helmi Abdul Latif, Diponegoro University, Indonesia. e-mail: helmiabdullatif@ yahoo.com

Received: September 5, 2019

Accepted: September 30, 2019

Online Published: October 01, 2019

DOI: $10.29408 /$ veles.v3i2.1568.g930

URL: http://dx.doi.org/ 10.29408/veles.v3i2.1568.g930

Abstract

This study aims to analyze the needs of students in learning English for special purposes (ESP) with the theme of Islamic boarding schools. Designed as descriptive qualitative, the researcher used questionnaire and interview to obtain data. The results show that there are differences in the English learning needs of students in Islamic boarding schools and students who are not in Islamic boarding schools. The subjects in pesantren can be used as English learning material for special purposes such as fiqh, history, ahlaq, da'wah, etc. In addition, learning English at Islamic boarding school-based institutions makes students get used to practice using English for daily activities.
\end{abstract}

Keywords: ESP, Islamic Borading School

\section{Introduction}

At present time, English is studied by many learners and even learners who specifically do not learn languages, such as technology, law, religion and others. In the various departments, English is intended as a supporting tool for learning, for example to enrich understanding because a lot of literature is translated into English. In addition, English is also intended as a tool of communication in the professional world when learners from various disciplines have graduated.

The number of existing scientific disciplines makes English less useful if studied / taught without considering language learners' discipline. So, there is a need for language learning that is focused and in accordance with the learners' discipline.

Needs according to Hutchinson and Waters (1987) are all those related to necessities, that are, what learners must know in order to play an active role in the language being studied; wants, that are things that encourage students want to learn languages; lacks, that are skills that need to be mastered by the learner. By analyzing these components, learning English will be in accordance with the needs of students so that students will get language experience in accordance with their knowledge. 
Islamic boarding schools are one of the institutions that intensively uses English to communicate, especially Islamic boarding schools with modern systems. Students in boarding schools are required to use English on certain days, while learning English still uses general English. This will make it difficult for students to use English if English taught is not in accordance with their theme, namely English which is related to the environment of Islamic boarding school. Wardhaugh (2006) stated that language environment is a community environment which the member can communicate using the same language, variations of the same language, and use the same language code. Therefore, the environment has an important role in language acquisition.

Teaching general English for language learners is indeed not entirely wrong because students must also master the basic material to learn language at a higher level. In addition, learning English that emphasizes the use of general English or national curriculum aims to make students able to pass the national exam with good grades.

However, for student of Islamic boarding school, learning English which only focuses on general English is considered still not enough. Student of Islamic boarding school is student who in the future are expected to become scholars, where the demands of learning for the students are quite high. Besides the student should study religious literature in Arabic, an Islamic scholar must also be able to access information from English literature as a consequence of the current development. Beside for being a tool for accessing literature, English for Islamic scholar is useful for $d a^{\prime} w a h$ and communication on a broader scope.

Therefore, Need analysis for designing ESP is very needed for student of Islamic boarding school to find out what material learners need. This research will analyze the appropriate materials and problems faced by students of Islamic boarding school Darul Muqorrobin. When need analysis has been done, the teacher can know what material is appropriate for learners and what difficulties students may get when learning English. After learners' needs and difficulties are known, the teacher can design English materials according to the needs of learners.

In relation to these needs, there are some previous studies relating to needs analysis in ESP. Like the research conducted by Sundari (2008) her thesis entitled English language learning for professional purposes. This research was conducted at the State Vocational High School (SMK N) 6 Jakarta. In addition to analyzing the needs of the school, the researcher also conducted an analysis of five companies around the school. This research aims to create an English syllabus for vocational high school (SMK) in the fields of business and management expertise that can prepare graduates ready to work, which is called the English for Occupational Purposes (EOP) syllabus. There are two main results from this thesis: (1) a list of English competencies that are useful in the world of work and (2) syllabus EOP. In addition to the two main results obtained, the study also produced two other findings, namely (1) weaknesses in learning English and (2) the similarity of the needs of parties related to learning English.

Aniqoh (2018) entitled need analysis of ESP materials for the medical laboratory technology students in the health polytechnics Semarang. This research aims to identify students' needs for English teaching materials for special purposes in the scope of the Medical Laboratory 
Technology Department in Semarang Health Polytechnic, and explore the needs of lecturers or instructors for appropriate teaching material for students majoring in Medical Laboratory Technology in the Semarang Health Polytechnic.

Suardi, Emzir, and Zainal Rafli (2017) entitled English learning in Islamic boarding school Al-Junaidiyah Biru Bone (ethnographic studies). This research uses ethnographic approach to analyze the environmental context. The results of the study show that (1) analyzing the needs and the environmental context in the formulation of learning objectives, (2) using 2 curriculum that is the curriculum of 2013 for general subjects and the curriculum of pesantren religious subjects, (3) adjustment of learning materials with context, social function, text structure, and linguistic elements, (4) using approach (Contextual Teaching and Learning-CTL), (5) Educators, and learners have a mutually exciting learning role to be interesting and fun, (6) developed language environments such as the implementation of English flag ceremonies, sports competitions and the arts that use English in extracurricular activities. The conclusion of the effort to habituate the use of English and has four language skills, namely listening, speaking, reading and writing.

\section{Method}

The study is qualitative research based on the results of questionnaire and interview of respondents which were analyzed qualitatively. The data obtained were analyzed to determine the needs of English learning in Islamic boarding school of Darul Muqorobin Kendal.

\subsection{Participants}

The respondents in this study were 93 students of Islamic Senior High School (MA) and one English teacher of Darul Muqorrobin Islamic Boarding School Kendal.

\subsection{Data Collection}

\subsubsection{Instrument of Collecting Data}

Instruments used in the research are questionaire and interview. The organization of the questionnaire refers to the theory of Oppenheim (1992). And the material in this questionnaire was developed from the theory of Graves (2000) adopted from Sundari (2008) and the theory of Duddley-Evans and St. John in Anik (2018) regarding needs analysis.

The interview in this study is a semi-structured interview adopted from Sundari's master thesis (2008). Semi-structured interview according to Johnson (1992) is an interview which the questions are in the form of an outline or main question. The purpose of the interview is to get data of subjective and qualitative perceptions.

\subsubsection{Techniques for Collecting Data}

The researcher give questionnaire to students. Then the results of the questionnaire are analyzed to find the difficulties and the approroate material for students. In addition, the researcher also interviewed the English teacher to get deeper research results. 


\subsection{Data Analysis}

Data obtained from the questionnaire is calculated to find the percentage of students' answers. Then the results are analyzed descriptively. Interviews were conducted to English language teachers and the results of the interviews were analyzed descriptively then presented systematically along with the results of the questionnaire analysis.

\section{Results and Discussion}

Duddley-Evans and St. John in Anik (2018) stated that there are five components of needs analysis which have been devided into:

\subsection{Target Situation Analysis and Objective Needs Analysis}

Target analysis and objective analysis are two things that are closely related. They relate to the purpose of learning English which is appropriate to what for learners are learning English. Therefore, by knowing the function / use of the learner's English, the learning design can be adjusted to what the future learners will use the language.

Santri, another name for Islamic boarding school students is students who are expected in the future to become Islamic expert. So, they have to study Islamic science in depth. The Islamic science is obtained from many references and literature, including Islamic literature in English. By designing English with a religious theme, at least they were introduced to Islamic terms and styles written in English. This is also in accordance with the vision of the Islamic boarding school (pesantren), namely to form a generation that has morality, knowledge, and integrity. From this vision, it is expected that after graduating students can become individuals who have virtue, knowledge and integrity.

Besides having a deep knowledge of Islam, students are also expected to teach others (da'wah). In this case, students must have good language and communication. For this reason, English language learning related to Islamic speech is also needed for student. In addition, conversations and discussions on the Islamic theme is also needed to be taught because students may interact with religious scholars from other countries, for example, if students continue their education abroad.

Interview conducted by researcher to the Englsih teacher showed that students have not received English language learning related to the theme of pesantren because the material taught is still general.

"the English learning that I gave is still general, I took it from English book prepared by the Ministry of Education. For now the focus of learning that I give to students is that students can do the exam well. The idea of English learning theme related to pesantren as you explained is very good"

Therefore, it is necessary to have an English learning design that is in accordance with the use of English by students, namely English can be used to study and access the Islamic literature, to communicate, and English is used for religious lectures. 


\subsection{Linguistic Analysis, Discourse Analysis, and Genre Analysis}

Linguistic analysis, Discourse analysis, and Genre analysis are three things that are needed by students so that the language they use can be useful in the future or in other words is in accordance with target situations.

The analysis conducted by the researcher on the language shows that the four skills namely speaking, writing, listening and reading, speaking and reading are needed by students to make English as a practical learning tool, or in other words must be mastered by students to support learning. This is in accordance with the vision of the pesantren that is to educate students to be religious experts. In addition, speaking and reading must be mastered by students because pesantren activities really need these skills, for example English speech activities.

Graves (2000) considered speaking English with friends, teachers and others as a component can be analysed to design ESP material. The intensity of students of senior high school (Madrasah Aliyah) of Darul Muqorobin Boarding School should be analysed in order to design ESP course.

From the data, the students' intensity in speaking english is in the low level. 77,4 \% of 93 students never speak englsih with friends, teachers and others. Speaking skill is really needed by students both when they are still in pesantren or after graduating from pesantren to continue their education. Speaking material about delivering speech is really needed by students. While the intensity of students in speaking is very low. This certainly must be addressed immediately by designing learning speaking skills wich may increase students' intensity to speak english.

The analysis conducted by the researcher on discourse found that teacher can give English learning materials and activities about delivering speech with the theme of Islamic big days, religious events, and national big days. In addition, for increasing reading skill, the teacher can give English texts about the sources of Islamic law, namely the Quran and Hadith, history, jurisprudence, aqidah, and ahlak. By teaching the Islamic literature in English, students are expected to be used to getting information from Islamic literature in English besides Arabic and Indonesian literature.

From the genre analysis the researcher found that English material that could be used at the target situation was highly needed by students. Such material, for example, descriptive, report, and Islamic-themed history can be given to students to increase students' reading skills on Islamic-themed reading. To practice speaking skills, the teacher can give materials on debating technique, delivering speech, and daily conversation in pesantren. The material may increase students' skills to communicate well and convey scientific ideas.

\subsection{Subjective Needs Analysis}

The subjective needs analysis addresses the wants, mean, and subjective needs of language learners. Analysis of student learning styles, namely about the material, learning process, and tasks that students must do can be the basis for designing ESP material.

\subsubsection{Theoretical English Learning Materials}

Teaching theoretical English material is generally too focused on teaching grammar. Grammatical skill is indeed important in language learning. However, it does not mean that 
grammar is taught separately without considering the integration of grammar in practical language learning. If grammar is taught separately, which in practice students are asked to memorize certain grammatical patterns, this will cause students get lack motivation to learn. This also will have an impact on the lack of students' skills in using English practically in certain domains, namely the daily life of pesantren students. For example, daily conversations in Islamic boarding schools, understanding English religious literature and speeches.

Data taken from the questionnaire showed that 13 students ( $13,9 \%$ ) of 93 students strongly agree with theoretical learning. 11 students ( $11,8 \%$ ) agree. 37 students ( $39,7 \%)$ disagree and 32 students ( $34,4 \%$ ) strongly disagree with theoretical learning. The data showed that accumulation of disagree and strongly disagree is 68 students ( $74,1 \%$ ) meaning that students do not like theoretical learning.

\subsubsection{Practical English Learning Materials}

Practical English learning material is very good for students because it will improve student performance in the use of English. Practical learning or performance-based learning is preferred by students. This can be seen from the data that 19 students ( 20,4\%) of 93 students strongly agree with theoretical learning. 48 students ( 51,6\%) agree. 11 students ( 11,8\%) disagree and 15 students $(16,1 \%)$ strongly disagree with practical learning. The data shows that $60,6 \%$ of students prefer practical learning.

\subsubsection{Lecture Method}

In the lecture method, the teacher talks a lot to explain the material. This can be a story or a long explanation from the teacher. In this method, students are not so active in practicing language. The emphasis in Bligh (2000) is mainly on the presentation of the topic and the explanation of the content to the students. As with other teaching methods in use, the lecture method gets a mixed view among different scholars. Although most of students have been inspired by brilliant lecturers, many learners have been bored, confused and even annoyed by inexperienced lecturers (Cannon \& Newble, 2002).

From the data, it showed 44 students $(47,3 \%$ ) disagree and 38 students ( 40,8 \%) strongly disagree with lecture method. This is natural because learning by the lecture method tends to be boring even though on the other hand it also has strength. Only 7 students ( 7,5\%) agree and 4 students $(4,3 \%)$ with strongly agree. it means that students do not like lecture method.

\subsubsection{Learners with more activity}

The next question is about the assignments / activities in English that students must do. This English assignment is a task given by the teacher to support student learning and understanding of English. From these questions, 70 students (75.2\%) of students chose answers agree and strongly agree with the learning activities. Other 23 students ( 24,7\%) choose answer disagree and strongly dissagree if they are given some activities as task. This shows that students like assignments that can increase their activeness in the use of English. 


\subsubsection{Individual assignment}

In individual assignments, students have their own tasks to complete. The data shows that $\mathrm{x}$ students prefer if the assignment is not done individually. only 22 students ( 23,6 \% ) agree if the work is done individually. 74 students ( $79,3 \%$ ) who disagree with individual assignments mean that they like group assignments. Among the interests of carrying out learning in groups is that students will be more open to sharing with other friends, which may not be acceptable if the assignment is done individually or shared with the teacher.

\subsection{Present Situation Analysis}

Presentation situation analyzes the current language use of learners. The results of this analysis can be used to determine the level of material in accordance with the student's current skills. Graves (2000) consider the circumstance and student's interest as components that can be analyzed to design ESP material.

\subsubsection{Learner's Circumstance}

Age is one component that needs to be analyzed to design ESP material. Like commonly the age of high school students, the age of students of Darul Muqorrobin Boarding school is between 15-18 years old. 8 students are 15 years old, 13 students are 16 years old. 41 students are 17 years old and 31 students are 18 years old. The formulation of material that can be given to the age of learners at this age is low level material. Teachers can provide easy material to students ranging from easy material to difficult material.

Students of Darul Muqorrobin senior high school (Madrasah Aliyah) generally have long studied English. The questionnaire shows that students have studied English for 7 years or in other words they have learned English since grade 4 of elementary school. So it can be concluded that students have been introduced or even have mastered basic English and the ESP syllabus which is based on topics of pesantren can be taught to students.

\subsubsection{Learner's Interest}

students' interest in English can be known from the questionnaire about the intensity of reading English literature, newspapers, magazines, and articles in English. Students are asked to choose answers, always, sometimes, rarely, and never. A rare criterion is if the activity is carried out less than three times then it is categorized as rare, whereas if more than three times it is categorized sometimes. From these questionnaires, researchers obtained data that 7 students ( $12.9 \%$ ) chose answers never. Students who choosed rarely answers are 37 students ( 39,7 \% ) and 46 students $(49,4 \%)$ choosed answers sometimes. Only 3 students of 93 students choosed always. From the questinaire, the researcher concludes that students' interest in reading is still low.

\subsection{Means Analysis}

Means analysis discussed the environment in which learning process will take place. Pesantren is a very good place to learn languages. In pesantren, there are at least a number of components why pesantren can be the right place to learn languages. In pesantren, the learning 
process used a boarding system where students live in a dormitory. The advantage of this system is that the teacher can design language learning more freely by coordinating with the boarding school administrators. With a boarding system, language learning can take place with a longer duration of time, for example by applying the English zone, or requiring students to use English on certain days. With the boarding-based language learning design, students will be more intensive in practicing the use of English with a longer duration of time even after school. Besides the advantage in terms of time, another advantage is in the activities of boarding school which is varied. It is very possible to integrate English, for example speech. In speech, students can directly practice public speaking which is one of the most important skills in language learning.

In addition, the theme of Islamic religious learning materials in Islamic boarding schools is very good as a theme in learning English. For example fiqh material, the teacher can provide texts on discussions about muamalah law for example buying-selling and Islamic economics, discussion of religious laws such as the laws in prayer, fasting, etc. as English learning material. Learning English by using these themes will make students have language experiences that are appropriate to their knowledge.

\section{Conclusion}

Pesantren is a very good place to learn language. Pesantren students' need is different from students in institutions that are not boarding-based system. Students' activities in pesantren are quite full, ie students must study religion deeply. In addition, students in pesantren tend to not be able to freely access learning resources such as the internet, English texts, audio, etc. However, this is not entirely an obstacle in learning English. Even it can be an advantage. With a dormitory-based education system, teachers can design language learning with a longer duration of time in daily activities.

\section{References}

Abdulbakili, K., Suhaimi, M., Alsaqqaf, A. \& Jawad, W. (2018). The Impact of Using The Lecture Method on Teaching English At University. European Journal of Education Studies, Vol 4(5), 285-302

Aniqoh, A. (2018). Need Analysis Of Esp Materials For The Medical Laboratory Technology Students In The Health Polytechnics Semarang. Thesis : Muhammadiyah University Of Surakarta

Bligh, D. A. (2000). What's the use of lectures? (1st Ed.). San Francisco: Jossey- Bass Publishers

Cannon, R. \& Newble, D. (2002). A handbook for teachers in universities and colleges: A guide to improving teaching methods. London: Kogan Page Ltd

Dudley-Evans, Tony and Maggie Jo StJohn. (1998). Development in English for Specific Purposes: A Multy-disciplinary Approach. Cambridge : Cambridge University Press.

Sundari, E. (2008). Pembelajaran Bahasa Inggris Untuk Tujuan Profesi Di Sekolah Menengah Kejuruan Negeri 6 Jakarta. Thesis : University of Indonesia 
Graves. K.(2000). Designing Language Courses: A Guide for Teachers. Boston: Heinle \& Heinle.

Hutchinson, Tom \& Waters, A. (1987). English for Specific Purposes: A Learner-Centered Approach. Cambridge : Cambridge University Press.

Oppenheim, A.N. (1992). Questionnaire Design, Interviewing and Attitude Measurement. (2nd ed.) London: Heinemann

Wardhaugh, Ronald. (2006). Sociolinguistics.Victoria: Blackwell Publishing. 